\section{Wirtschaftliche Effekte des Tourismus in Biosphärenreservaten Deutschlands}

Job, H., F. Kraus, C. Merlin \& M. Woltering 2014.

Naturschutz und Biologische Vielfalt, 134, BfN,

Bonn-Bad Godesberg. ISBN: 978-3-7843-4034-0

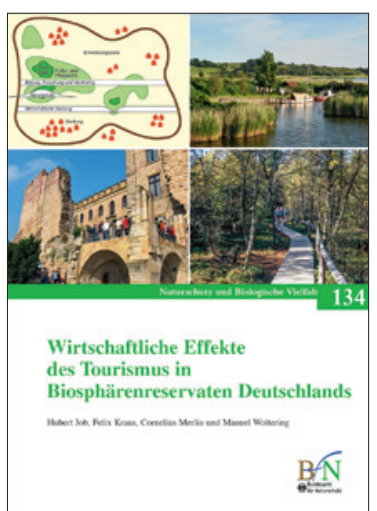

The management of large protected areas today has to meet additional societal expectations beyond conservation tasks and landscape protection. These include regional development and planning for the future in general, as well as a special focus on developments in tourism (cf. Weixlbaumer et al. 2014, in print). This is precisely the range of themes addressed by this volume, created by a team of authors around Hubert Job. The book, published by the German Federal Agency for Nature Conservation, builds on insights from the study of regional economic effects of tourism in German national parks (Job et al. 2009) and is structured as outlined below.

It starts with a general overview of the areas of tension between biosphere reserves (BRs) and tourism. This chapter sketches the international development of the BR concept as well as the domestic situation in Germany. It points out the far-reaching aims of BRs, then goes into more detail on the conflicts between conservation and tourism against the overall aim of sustainable regional development.

The second chapter provides a short but knowledgeable summary on destination management in German BRs. It demonstrates how, as soon as a protected area is designated and its management set up, the complex interwovenness of actors in the destination system changes. Overall, the BRs are thought to have considerable potential as destinations on the tourism market because of their natural and cultural landscape prerequisites. In many cases, however, this potential remains untapped. After an introduction to the theme, this chapter details the method of empirical analysis of the research and development project, taking into account the insights from the above mentioned national park study.

Core elements of the method are a quantitative analysis of secondary statistical data and a qualitative analysis based on a semi-structured survey session from the years 2008 and 2010. The German BRs are grouped along the indicators of overnight stays and tourism density. The classification is as follows and includes sample cases: i) very large traditional tourist region (e.g. southeastern Rügen); ii) large tourist region (e.g. Rhön); iii) medium-sized tourist region (e.g. Spreewald forest) and iv) small tourist region (e.g. Schaalsee).
All BRs not directly investigated in the study were allocated within this classification to arrive at an overall typology of BRs and their strengths as destinations and as BRs. Limited time and funds forced the authors, as in most studies, to proceed by selecting sample sites.

Later chapters on the economic analysis of tourism in BRs then elaborate as necessary on the methodology, detailing the methods used to calculate regional economic effects, visitor numbers and composition, as well as those used to identify the potential for natureoriented leisure and tourism options.

Overall the book takes up the challenge of extrapolating the economic effects from the empirical results of six studied BRs to all German BRs with the help of the classification listed above. To their credit the authors admit openly that the results of this extrapolation cannot match an actual survey in terms of accuracy. Rather they represent a guiding level to be validated by potential follow-on research. One of the key results is the calculated volume of ". .65 .3 million tourists in German biosphere reserve regions generating a volume of 2.94 billion euros" (p. 154,). "In total this means a calculated equivalized disposable income of more than 86200 euros" (ibid., transl. by the reviewer).

In connection with the comparable studies referred to above, I would like to mention one more significant achievement of this book, i. e. the analysis of spending behaviour.

According to this study, spending behaviour in BRs is more intensive than in national parks. The main reason put forward in this book is the greater range of options for consumption in these cultural landscapes. Indeed, the inherent concept of graded land use (after Haber) in BRs and the smaller required core zones (3\% in Germany or $5 \%$ in Austria), compared to national parks by IUCN standards, mean that BRs present a higher degree of hemeroby and thus more diverse possibilities for consumption. Such an argument must of course not lose sight of the regional differences or the structural and overall economic framework conditions. What is needed here is a case by case review and argumentation.

In its entirety the study provides clear arguments for the economic relevance of large protected areas. For the BRs this supports findings that are already evident at the level of nature and national parks (cf. Job 2008; Heintel \& Weixlbaumer 2009; Ketterer \& Siegrist 2009; Mayer 2013 and many others). It fills a major gap in the arguments around the relation of large protected areas and sustainable development in the regions. The volume is a firm building block in protected area research.

Norbert Weixlbaumer, Department of Geography and Regional Research, University of Vienna

\section{References}

Heintel, M. \& N. Weixlbaumer 2009. Die regionalökonomische Bedeutung des österreichischen Naturparktourismus. Natur und Landschaft 7 (84): 315-321. 
Job, H. (Hrsg.) 2008. Die Destination Nationalpark Bayerischer Wald als regionaler Wirtschaftsfaktor. Grafenau.

Job, H., M. Woltering \& B. Harrer 2009. Regionalökonomische Effekte des Tourismus in deutschen Nationalparken. Naturschutr, und Biologische Vielfalt 76. Bonn-Bad Godesberg.

Ketterer, L. \& D. Siegrist 2009. Touristische Potenziale der Österreichischen Naturparke. Rapperswil.

Mayer, M. 2013. Kosten und Nutzen des Nationalparks Bayerischer Wald. Eine ökonomische Bewertung unter Berücksichtigung von Tourismus und Forstwirtschaft. München.

Weixlbaumer N., D. Siegrist, I. Mose \& T. Hammer 2014 (im Druck): Großschutzgebiete als Instrumente für zukunftsorientierte Regionalentwicklung in Europa - die Sicht der Schutzgebietsverantwortlichen und Forscher am Beispiel von Partizipation und Regional Governance. In: Bork, H.-R., K.-H. Erdmann \& H. Job (Hrsg.), Schutagebiete in Gegenwart und Zukunft (=BfN-Skripten). Bonn-Bad Godesberg.

\section{Reservas de la Biosfera de Chile - Laboratorios para la Sustentabilidad}

Moreira-Muñoz, A. \& A. Borsdorf eds. 2014. ISBN-978-956-14-1390-0

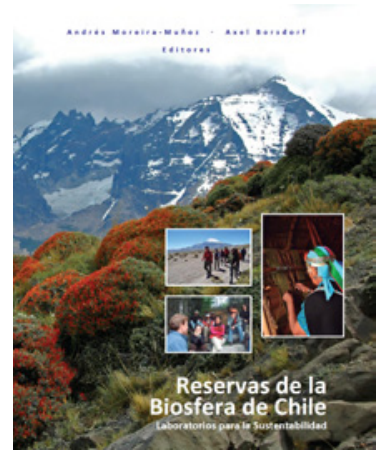

It is a great pleasure to have in my hands this wonderful book about the biosphere reserves of Chile, edited by Andres Moreira-Munoz and Axel Borsdorf. This is a work of great vision that recognizes the historical challenges that Ibero-America and the Caribbean have faced and the conversion of its cultural and biological diversity to the basis of development and well-being for the population of the region. This book offers a glimpse of biosphere reserves as laboratories of sustainability, from a perspective that aims to conserve the natural and cultural capital of Chile that is threatened by accelerating global and regional changes and with the ultimate goal of incorporating its benefits in the daily life of the population.

The book describes the characteristics of the biosphere reserves and highlights their importance among the distinct categories of existing protected areas, emphasizing their significance as a model for territorial planning that is capable of promoting a more harmonious relationship between society and nature.

Across its ten biosphere reserves, Chile harbours some of the most spectacular ecosystems and natural landscapes of mountains, coasts, glaciers and archipelagos, dispersed throughout the length of its geographically diverse territory and even including the southernmost biosphere reserve of the continent,
Cabo de Hornos. These spaces are of great biogeographical and ecological importance for safeguarding the biodiversity of the American continent.

The progress achieved jointly by the Chilean government and scientists is especially notable in their resulting capacity to adapt and redesign the reserves, with attention to the proposals from the Seville Strategy, its Statutory Framework, and the Madrid Action Plan 2008-2013. The National Forest Committee (CONAF), in collaboration with the Territorial Planning Department and the Management of Chilean Natural Protected Areas, has been a strong supporter of this effort, not to mention the enthusiasm of Pedro Araya, who has led the efforts to comply with the MAP framework within the Biosphere Reserve Network of Ibero-America and the Caribbean (IBEROMaB), which represents an evaluation that will determine the future of this network and the global network of biosphere reserves.

The Chilean biosphere reserves form a very active part of the IBEROMaB network National Committees and the Biospheres Reserves of Ibero-America and the Caribbean, a regional network that maintains an intense and continuous interchange of experiences between the reserves' management and the committees, which has produced notable results, such as the first Ibero-American Conference of Biosphere Reserves in Puerto Morelos, Mexico, and the Action Plan of IBEROMaB, PAI, 2010-2020.

The editors and authors of the book and its various chapters point out with much clarity the challenges facing each of the biosphere reserves of the region and their unique perspectives. It is a an exemplary work that contributes to guiding future efforts to create new reserves in regions of pressing importance, which, I should mention, will also contribute to the promotion of new reserves in other countries throughout the region. This is an invaluable archive of experiences to share with others in the network Biosphere Reserves of Ibero-America and the Caribbean.

During recent reunions with the IBEROMaB network, we have commented on the necessity for establishing a diagnostic system and corresponding analysis of existing biosphere reserves, including: i) a description of the characteristics of each reserve, ii) a clear cartography of the zonation and the vegetation types located within the reserve, iii) an estimate of each reserve's biogeographical and ecological representativeness, and finally iv) an archive of distinctive photographs that record each reserve's landscape and biodiversity.

This book exceeds the above-mentioned expectations. It is a work that awakens an admiration for nature and inspires innovations in the conservation of the diversity of landscapes in favour of sustainable development, and above all, represents a compelling call to action.

Sergio Guevara S., Vice-president for Latin-America, International Co-ordinating Council, MaB Pro-

gramme, MaB, UNESCO 


\section{AfriMAB - Biosphere Reserves in Sub-Saharan Africa: Showcasing Sustainable Development}

Pool-Stanvliet, R. \& M. Clüsener-Godt (eds.) 2014. Department of Environmental Affairs, Directorate: Protected Areas Planning, Legislation, Compliance and Monitoring and UNESCO - Devision of Ecological and Earth Sciences. ISBN 978-0-620-57141-8

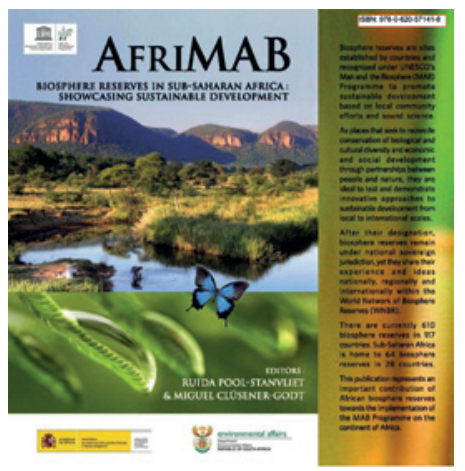

There is more genetic diversity between different African people than between all the races of the world combined. The continent is home to multiple ethnic, cultural, racial, religious, socio-economic, gender, political and biological markers that define the plurality of identities. Africa has 3000 distinct ethnic groups, 2000 languages and is home to the most genetically diverse people on Earth. Therefore, diversity is one attribute that anyone considering the continent is immediately impressed with and which makes the continent second to none in the world. The nature and extent of diversity in Africa is also an opportunity for progress and sustainability. This is because it offers an avenue for exchange, innovation and creativity in finding solutions to society's problems.

Africa is the world's second-largest and secondmost-populous continent. It occupies a wide dynamic latitude and includes deserts, forest, snow, temperate climate, tropics, sub-tropics, lakes, the longest river, the lowest point on Earth and high mountains. The book AfriMAB provides a description of biosphere reserves in sub-Saharan Africa in 21 research papers from nine African countries. These biosphere reserves cover a panorama of topographic and land-cover types, e. g. forests, mountains, lakes, canyons and bird areas. All these places, as biosphere reserves, seek to reconcile conservation of biological, cultural diversity with economic and social development without compromising human benefits and ecosystem quality. The research papers presented show how local people are able to participate positively using their traditional knowledge with innovative approaches to demonstrate sustainable management and development of these diverse ecosystems.

The strengths in the 21 chapters of this book are multifaceted. (i) It demonstrates that the past view of nature protection policy that created closed areas is now being adjusted effectively in biosphere reserves where humans and wild species can share common ground and prosper in both conservation and sustainable development. (ii) It demonstrates the active role of the AfriMAB network that integrates biodiversity conservation activities and connects 64 biosphere reserves in 28 sub-Saharan countries. (iii) It showcases nine of these biosphere reserve management systems, and shows how the conservation of natural resources through such a system can be seen as life support for local people. And finally (iv): Given the environmental degradation arising from depletion of biodiversity, deforestation, soil erosion, climate change and poverty, this book can play a role in encouraging the high level authorities in Africa to give more consideration to environmental management challenges, and designate more sites as biosphere reserves wherever biodiversity is otherwise at risk.

The book reflects on the particular importance of the transboundary biosphere reserves which create space for the cross-border planning. This model takes into account the diversity of existing ecosystems, planners, authorities, local inhabitants and concessionaries sharing the boundaries of the system and the site. The model recognizes that all actors are oriented towards profitability and seeks win-win solutions through which everybody benefits while sharing common grounds for natural resource conservation.

Each of the 21 papers reflects its author's passion for their local habitats and demonstrates the unique role that is played by biosphere reserves in supporting community development, empowering poor rural people and conserving nature. Several methodologies have been used in the 21 research papers, including questionnaires, field surveys, lab experiments, experiments, statistical analysis and spatial data analysis using GIS and remote sensing. Individually or combined, these are effective in producing valuable usable information and results and reaching solid conclusions based on which decision could be made. Lessons learnt from the 21 papers concern the strategic vision on capacity building that is needed for biosphere reserve managers.

This book will inspire reserve managers to pursue priority projects aimed at innovatively addressing challenges and opportunities facing sensitive ecosystems, including social inequality and exclusion, zonation schemes with sound underpinning, which is critical for long-term sustainable development. The public-private partnership management arrangement is important in promoting innovative approaches to multi-sectoral and multi-stakeholder based sustainable management systems in biosphere reserves. Such systems ensure local participation and motivation and creation of the sense of responsibility towards natural resources and ecosystem services and their limitations.

Dr. Boshra Salem (University of Alexandria, Egypt). President of the MAB International Coordinating Council, Chair of the Department of Environmental Sciences of the Alexandria University (Egypt), since 2013 member of United States Department of State "Women in Science Hall of Fame", winner of the UNESCO Sultan Qaboos Prize for Environmental Preservation 